\title{
A REVITALIZAÇÃo do CAIS MAUÁ, EM PORTO ALEGRE, NA PERSPECTIVA DA GEOGRAFIA JURÍDICA
}

\section{THE REVITALIZATION OF MAUA PIER, IN PORTO ALEGRE, FROM THE PERSPECTIVE OF LEGAL GEOGRAPHY}

Lucas P. Konzen ${ }^{1}$

Mariana M. Vivian ${ }^{2}$

\section{RESUMO}

Este artigo tem por objetivo discutir as mudanças na regulação dos usos dos espaços públicos em projetos de revitalização urbana de áreas portuárias por meio do estudo do caso do Cais Mauá, em Porto Alegre. Categorias do campo da geografia jurídica serviram de referencial teórico tanto para desenhar a pesquisa empírica qualitativa quanto para analisar os dados coletados. As fontes de informação sobre o projeto de revitalização incluem documentos normativos e administrativos, notícias da imprensa local e cartas abertas publicadas em redes sociais por movimentos de contestação ao projeto. $\mathrm{O}$ artigo sustenta que os processos de revitalização urbana de áreas portuárias representam mudanças na regulação dos usos dos espaços públicos. No caso estudado, as mudanças previstas tendem a resultar na separação entre a área portuária e o entorno no que se refere às normas jurídicas que regulam os usos dos espaços urbanos.

Palavras-chave: geografia jurídica; revitalização urbana; espaços públicos; Porto Alegre; Cais Mauá.

\section{ABSTRACT}

This article aims at discussing the changes in the regulation of the uses of public spaces in urban revitalization projects of port areas through the study of the case of Maua Pier, in Porto Alegre. Categories of the field of legal geography served as a theoretical framework both to design the qualitative empirical research and to analyze the data collected. The sources of information on the

\footnotetext{
${ }^{1}$ Professor de Sociologia do Direito da Universidade Federal do Rio Grande do Sul (UFRGS). Doutor em Direito e Sociedade pela Università degli Studi di Milano, Itália. Membro permanente do corpo docente do Programa de Pós-Graduação em Direito (PPGDir-UFRGS). Líder do Grupo de Pesquisa Direito e Sociedade (GPDS-UFRGS). ORCID iD: https://orcid.org/0000-0002-0376-3770 URL: http://buscatextual.cnpq.br/buscatextual/visualizacv.do?id=K4130891A1 Lattes: http://lattes.cnpq.br/2445866326438476E-mail: lucaskonzen@ufrgs.br

${ }^{2}$ Bacharela em Ciências Jurídicas e Sociais e Mestre pelo Programa de Pós-Graduação em Sociologia da UFRGS. Mestranda em Sociologia do Direito no Oñati International Institute for the Sociology of Law, Espanha. Foi bolsista de iniciação científica da Fundação de Amparo à Pesquisa do Estado do Rio Grande do Sul (FAPERGS) e integrou do Grupo de Pesquisa Direito e Sociedade (GPDS-UFRGS).ORCID iD: https://orcid.org/0000-0001-5687-782X E-mail: marianavivian@live.com
} 
revitalization project include normative and administrative documents, local press news and open letters published on social media by movements in opposition to the project. It is argued in the article that the processes of urban revitalization of port areas represent changes in the regulation of the uses of public spaces. In the case studied, the expected changes tend to result in the separation of the port area from the surroundings in respect to the legal norms that regulate the uses of urban spaces.

Keywords: legal geography; urban revitalization; public spaces; Porto Alegre; Maua Pier.

\section{INTRODUÇÃO}

As políticas de revitalização urbana de áreas portuárias constituem um fenômeno relativamente recente no Brasil. A despeito da multiplicidade de projetos deste tipo em andamento em diversas cidades do país, do propalado impacto socioeconômico e dos acirrados conflitos que vêm provocando, as pesquisas que voltam seu olhar para esses processos de transformação espacial são escassas. É ainda menor a atenção dispensada aos aspectos jurídicos e sociais desses processos, embora se saiba o quanto as normas jurídicas são importantes para respaldar tais iniciativas e o quanto disputas materiais e simbólicas invariavelmente acabam por envolver agentes e instituições do campo jurídico.

Este artigo tem por objetivo discutir, na perspectiva da geografia jurídica, as mudanças na regulação dos usos dos espaços urbanos em projetos de revitalização de áreas portuárias. Ainda incipiente no Brasil, a geografia jurídica é um campo de pesquisa transdisciplinar que vem se desenvolvendo internacionalmente desde a década de $1990,{ }^{1}$ tendo surgido a partir do entrecruzamento de estudos sociojurídicos e estudos de geografia humana crítica voltados à investigação das inter-relações entre o direito e o espaço (destacam-se, entre outras obras seminais, BLOMLEY, 1994; e BLOMLEY; DELANEY; FORD, 2001). Na perspectiva da geografia jurídica, o espacial e o jurídico são dimensões mutuamente constitutivas da vida social (DELANEY, 2010, p. 7-8).

O caso da revitalização urbana do Cais Mauá, em Porto Alegre, foi tomado como exemplo empírico que ilustra o fenômeno investigado. Desde 2010, com a formulação de um projeto oficial de revitalização pelo Governo do Estado do Rio Grande do Sul em acordo com um grupo empresarial privado, pretende-se transformar a área portuária desativada da cidade em um complexo turístico, comercial e de negócios. A divulgação desse projeto, todavia, desencadeou um conflito urbano, alavancado pelo surgimento de movimentos de contestação que questionam tanto 
o déficit democrático na concepção da proposta quanto as suas implicações para os habitantes da metrópole.

O que as disputas em torno do projeto de revitalização do Cais Mauá significam em termos de mudanças na regulação dos usos deste espaço urbano? Buscando responder a este problema de pesquisa, a investigação orientou-se pela estratégia do estudo de caso, uma vez que intentou apreender um fenômeno contemporâneo complexo considerando a singularidade de sua manifestação em um contexto da vida real (YIN, 2001). As categorias da geografia jurídica serviram de referencial teórico tanto para desenhar a pesquisa empírica qualitativa quanto para analisar os dados coletados. As fontes de informação sobre o projeto de revitalização incluem documentos normativos e administrativos, notícias veiculadas pela imprensa local e cartas abertas publicadas em redes sociais por movimentos de contestação.

A exposição está organizada em quatro seções. A primeira seção discute a problemática dos processos de revitalização urbana, com foco nas transformações nos usos econômicos das áreas portuárias urbanas e na legislação que regula a gestão dessas áreas no Brasil. A segunda seção explica teorias da geografia jurídica sobre a produção social do espaço urbano e a sua regulação, especificando categorias úteis para analisar o caso da revitalização do Cais Mauá. A terceira seção detalha o projeto de revitalização urbana da área portuária de Porto Alegre apresentado pelo governo estadual em parceria com uma empresa privada e narra as disputas que emergiram a partir do surgimento de movimentos de contestação. Por fim, a quarta seção analisa os dados empíricos à luz das categorias teóricas da geografia jurídica, evidenciando que as mudanças previstas no projeto de revitalização do Cais Mauá tendem a resultar na separação entre a área portuária e o entorno no que se refere às normas jurídicas que regulam os usos dos espaços urbanos.

\section{OS PROCESSOS DE REVITALIZAÇÃO URBANA DE ÁREAS PORTUÁRIAS}

Nos debates sobre política urbana e na literatura especializada, a expressão revitalização urbana é utilizada para fazer referência a um fenômeno multidimensional (político, econômico, jurídico etc.) que se manifesta nas mais diversas cidades. Em termos simplificados, entende-se por revitalização urbana a transformação de determinado lugar da cidade consolidada por um conjunto de intervenções arquitetônicas, urbanísticas e paisagísticas planejadas com o propósito de resultar em novas configurações espaciais. ${ }^{2}$ Essas intervenções mostram-se mais complexas do que aparentam na medida em que implicam mudanças nas relações sociais inerentes ao espaço transformado. 
Os processos de revitalização urbana podem estar, por exemplo, associados à gentrificação, isto é, à produção de espaços destinados prioritariamente às demandas das camadas sociais economicamente privilegiadas (entre tantos, cf. SMITH, 2006). Sabe-se que intervenções arquitetônicas, urbanísticas e paisagísticas inscrevem no espaço revitalizado determinados valores, visões de mundo e estilos de vida vinculados a certos grupos sociais. A desconsideração em relação às necessidades dos usuários tradicionais do lugar, o incentivo aos usos que asseguram maior rentabilização econômica, a conversão do patrimônio histórico-cultural em atração turística e a preferência por orientações estéticas voltadas às elites globalizadas estão entre as características dos projetos de revitalização urbana que unem estratégias de transformação do espaço e gentrificação. $^{3}$

No entanto, as estratégias de revitalização e gentrificação que buscam segregar espaços urbanos tornando-os enclaves para o consumo turístico nem sempre desencadeiam um esvaziamento de seu sentido público. É que novas formas cotidianas de apropriação política desses mesmos lugares tendem a surgir, convertendo-os em locais de disputas materiais e simbólicas em torno do direito de estar na cidade e impulsionando o encontro das diferenças que permitem que continuem a se qualificar enquanto espaços públicos (ver, por exemplo, LEITE, 2004). Isso significa que as novas configurações espaciais resultantes dos processos de revitalização urbana não são determináveis de antemão; ao contrário, os espaços produzidos tendem a ser o resultado dos conflitos sociais inerentes aos processos de produção capitalista do espaço.

\section{As transformações nos usos econômicos das áreas portuárias urbanas}

As áreas portuárias, historicamente imprescindíveis para a inserção dos centros urbanos nas cadeias de circulação de pessoas e mercadorias, por muito tempo cumpriram o papel de espaços públicos por excelência no cotidiano das cidades. Em fins do século XX, todavia, tal situação modificou-se dramaticamente, uma vez que a disseminação da tecnologia de transporte e armazenagem de cargas em contêineres padronizados passou a exigir instalações portuárias de maior dimensão, altamente mecanizadas e com acesso estritamente controlado. As representações imagéticas negativas do "obsoleto", "sujo", "degradado", "abandonado" e "desregulado" paulatinamente passaram a ser associadas às áreas portuárias tradicionais, cuja vitalidade enquanto espaços públicos reduzia-se em simultâneo à transferência da maior parte das operações portuárias para enclaves industriais distantes do centro histórico.

A partir de tais transformações, as áreas portuárias em desuso tornaram-se alvos frequentes de projetos de revitalização urbana, seja por se situarem em terrenos extensos e 
centrais, seja por estarem à beira de corpos ou cursos de água de interesse paisagístico e integrarem o patrimônio histórico-cultural das cidades. É o que ocorreu no Port Vell, em Barcelona (Espanha); no Porto Antico, em Gênova (Itália); no Victoria \& Alfred Waterfront, na Cidade do Cabo (África do Sul); no Inner Harbor, em Baltimore (Estados Unidos); no Puerto Madero, em Buenos Aires (Argentina), entre tantos outros casos. A partir do encerramento das atividades portuárias e da implementação de projetos de revitalização urbana, essas áreas deram lugar a complexos que contam com uma variedade de atrativos, como centros de eventos, lojas, restaurantes, escritórios, hotéis, cinemas, cassinos, museus, aquários, marinas desportivas, rodas-gigantes, elevadores panorâmicos etc. Ainda que a combinação específica dos atrativos replicados possa variar, assim como o regime jurídico adotado em cada iniciativa, em comum a esses projetos está o intento de transformar as áreas portuárias em distritos turísticos, gerando novas centralidades urbanas.

Na esteira dessas experiências, projetos de revitalização urbana de áreas portuárias passaram a ser planejados também no Brasil, gerando processos de transformação em diversas cidades, marcadamente no contexto da Copa do Mundo de Futebol de 2014 e dos Jogos Olímpicos de 2016. O projeto Porto Maravilha, na cidade do Rio de Janeiro, é sem dúvida a mais complexa iniciativa do gênero em desenvolvimento no país, atingindo diretamente cerca de cinco milhões de metros quadrados, declarados Área Especial de Interesse Urbanístico. Para promover a revitalização urbana, a Prefeitura Municipal utiliza um instrumento previsto no Estatuto da Cidade (BRASIL, 2001), a operação urbana consorciada. Para gerir o projeto, foi criada uma Companhia de Desenvolvimento Urbano. A arrecadação de recursos para custear as obras e serviços públicos da operação urbana, executados por meio de uma Parceria Público-Privada, ocorreu mediante a emissão de Certificados de Potencial Adicional Construtivo (CEPACSs). ${ }^{4}$

Ainda que de menor envergadura que o Porto Maravilha, outras duas iniciativas emblemáticas em andamento no Brasil são os projetos de revitalização do Cais José Estelita, no Recife, e do Cais Mauá, em Porto Alegre - que será analisado em detalhes neste artigo. O Projeto Novo Recife surgiu a partir da compra em leilão, por um consórcio de empreendedores imobiliários, do terreno em que situavam algumas das instalações portuárias desativadas da cidade, antes pertencente à União Federal. A revitalização urbana da área do Cais Estelita prevê a criação de um novo bairro, contemplando obras viárias e um conjunto de edificações voltadas a usos residenciais e comerciais, com ênfase em serviços de hotelaria, gastronomia, cultura e entretenimento. ${ }^{5}$

Tais iniciativas, entretanto, vêm despertando diversas controvérsias quanto aos seus pressupostos e implicações, o que se reflete em uma polarização de posicionamentos políticos quanto à conveniência de sua concretização. No caso do Porto Maravilha, possíveis impactos como 
a aceleração do processo de gentrificação e a remoções de família moradoras do local em situação de vulnerabilidade social foram duramente criticados por movimentos de contestação ao projeto. ${ }^{6}$ O Projeto Novo Recife, por sua vez, desencadeou o surgimento do Ocupa Estelita, um movimento de contestação que contribuiu para provocar a rediscussão da proposta apresentada pelos empreendedores imobiliários ${ }^{7}$ - quadro que se repetiu, como se verá, no caso do Cais Mauá. Em meio a essas disputas, vieram à tona questões atinentes à legislação que regula a gestão das áreas portuárias no Brasil.

\section{Aspectos jurídicos da gestão das áreas portuárias no Brasil}

Há inúmeras insuficiências no tocante ao tratamento do tema dos bens públicos na dogmática do direito público brasileiro, situação que em nada favorece a compreensão do marco regulatório da gestão das áreas portuárias. Em meio ao emaranhado de diplomas legislativos, a Lei n. 12.815 , de 05 de junho de 2013, conhecida como Lei dos Portos, é ponto de partida obrigatório nessa análise (BRASIL, 2013). Contudo, como se pode facilmente perceber, a definição de "área do porto organizado" encontrada na Lei dos Portos não é equivalente ao conceito de áreas portuárias utilizado nos estudos urbanos.

A Lei dos Portos define como "área do porto organizado" (artigo 2ㅇ, II) a "área delimitada por ato do Poder Executivo que compreende as instalações portuárias e a infraestrutura de proteção e de acesso ao porto organizado" (BRASIL, 2013). ${ }^{8}$ Nos termos da lei (artigo 15), compete ao Presidente da República delimitar a poligonal correspondente a cada área de porto organizado (BRASIL, 2013). Trata-se, na dogmática do direito administrativo, de um ato de afetação formal de um conjunto de bens imóveis a uma finalidade pública específica de interesse da União, a atividade portuária. A área do Porto Organizado de Porto Alegre, por exemplo, foi delimitada pelo Decreto de 03 de junho de 2015 (BRASIL, 2015).

Constata-se, assim, que, na perspectiva do direito administrativo, a área do porto organizado abrange um conjunto de imóveis que são classificados como bens públicos de uso especial, ${ }^{9}$ os quais pertencem ao patrimônio da União, estando sujeitos ao seu poder de disciplinamento e regulamentação. ${ }^{10} \mathrm{~A}$ esse respeito, cumpre sublinhar que tais imóveis inseremse na categoria de bens de uso especial enquanto estiverem vinculados à destinação pública de interesse da União, isto é, ao uso para fins de operações portuárias. Uma vez formalmente extinta a área do porto organizado, pode-se falar em desafetação desses bens públicos, que passam a ser considerados bens dominicais, sem uma destinação pública específica definida. 
No tocante à exploração das atividades portuárias, de acordo com a Constituição Federal (artigo 21, XII, f), esta pode se dar diretamente pela União ou, de forma indireta, mediante autorização, concessão ou permissão (BRASIL, 1988). A Lei n. 9.277, de 10 de maio de 1996, autorizou a União a delegar a exploração dessas atividades aos demais entes federativos, por meio da celebração de convênios, cujo prazo é de até 25 anos, prorrogáveis por igual período (BRASIL, 1996). Na hipótese de delegação, cabe aos Estados ou aos Municípios explorar as atividades portuárias de forma direta ou indireta. No caso do Cais Mauá, a exploração das atividades portuárias foi delegada pela União ao Estado do Rio Grande do Sul em 1997, mediante a celebração de convênio de 25 anos (BRASIL, 1997).

Uma das principais inovações da Lei dos Portos ${ }^{11}$ diz respeito à exploração indireta das atividades portuárias (artigo 1ำ, $2^{\circ} \circ$ ), mediante contratos de concessão e arrendamento (BRASIL, 2013). Nos termos da lei, o arrendamento (artigo 2ํㅡ, XI) consiste na "cessão onerosa de área e infraestrutura públicas localizadas dentro do porto organizado, para exploração por prazo determinado" (BRASIL, 2013).

A Lei dos Portos, todavia, silencia acerca da situação cada vez mais recorrente de utilização para outras finalidades das áreas de porto organizado que, por diversos fatores, deixaram de ser operacionais. Há apenas uma indicação (artigo 19) no sentido de que podem ser exploradas direta ou indiretamente as áreas não destinadas à movimentação de passageiros e cargas ou à armazenagem de cargas provenientes do transporte aquaviário (BRASIL, 2013). Desta lacuna na legislação federal resulta a importância de uma portaria normativa posteriormente editada pela Secretaria de Portos, órgão vinculado à Presidência da República, visando regular a exploração de áreas portuárias não operacionais para fins de revitalização urbana. A Portaria n. 114, de 23 de março de 2016, considera que a "revitalização de zonas portuárias" (artigo 2으, II) envolve a "requalificação de áreas e instalações para a realização de atividades institucionais, culturais, sociais, recreativas, comerciais, ou outras", a ser viabilizada por meio de "projetos de readequação ou de integração urbano-portuária, a serem desenvolvidos dentro ou no entorno das áreas sob gestão da Administração do Porto" (BRASIL, 2016). Como se vê, a definição de "zonas portuárias" da Portaria n. 114/2016 guarda maior afinidade com o conceito de áreas portuárias utilizado nos estudos urbanos.

Depreende-se dessa discussão que os projetos de revitalização urbana de áreas portuárias podem tanto abarcar, parcial ou totalmente, a área do porto organizado e, assim, bens públicos de uso especial do patrimônio da União, como também envolver o seu entorno e, por conseguinte, outros bens de titularidade pública ou privada. No caso da revitalização do Cais Mauá, o projeto 
limita-se à área do porto organizado, ao passo que no Porto Maravilha tem-se uma operação urbana que se estende a uma série de imóveis do entorno. Há ainda a hipótese que se configura no Novo Recife, cujo projeto não envolve propriamente uma área de porto organizado, mas bens imóveis de titularidade privada, adquiridos em leilão promovido pela União. À medida que as áreas portuárias tradicionais das cidades deixam de cumprir com suas finalidades originais e passam a ser alvo de projetos de revitalização urbana, abre-se um leque complexo de alternativas de composição de relações de propriedade que conferem novos contornos à regulação jurídica desses espaços urbanos.

\section{A PERSPECTIVA DA GEOGRAFIA JURÍDICA}

A geografia jurídica proporciona ferramentas teóricas para compreender essas mudanças na regulação das áreas portuárias desencadeadas pelos projetos de revitalização urbana, bem como suas implicações para a conformação de configurações espaciais dotadas de sentido público. Nesse sentido, o marco teórico do presente estudo é constituído por teorias sobre a produção social dos espaços urbanos e sua regulação jurídica.

\section{A teoria da produção do espaço}

Os estudos urbanos que emergiram na década de 1970, responsáveis por resgatar de forma crítica a herança teórica marxista e edificar o paradigma socioespacial em sociologia urbana, desenvolveram a tese de que a espacialidade da vida em sociedade é resultado de um processo social de produção. De acordo com essa tese, os espaços refletem e condicionam as relações sociais, constituindo um equívoco teórico reduzi-los a simples receptáculos passivos dessas mesmas relações. ${ }^{12}$

Conforme a teoria de Lefebvre, que influenciou decisivamente a geografia jurídica, uma tríade de categorias permite analisar a produção espaço: "representações do espaço", "espaços de representação" e "prática espacial" (1974, p. $48-49$ e ss.).

As representações do espaço fazem referência aos espaços concebidos pelos grupos sociais hegemônicos, os quais controlam o processo de produção do espaço em uma dada sociedade. Nas sociedades capitalistas, são concebidas por urbanistas, empreendedores imobiliários e tecnocratas da gestão e do planejamento; portanto, são permeadas por um saber (uma mistura de conhecimento e ideologia) que, embora relativo, se impõe como técnico. As representações do espaço assumem caráter normativo, na medida em que definem usos, presenças e discursos incentivados ou permitidos em determinados lugares. 
Já os espaços de representação estão relacionados aos espaços vivenciados, que são essencialmente dinâmicos por abranger memórias de experiências passadas, situações imaginadas e desejos em relação ao espaço. Remetem aos espaços dominados em uma determinada sociedade, que estão associados aos grupos sociais não hegemônicos. Assim, os espaços de representação, ao desafiar a ordem normativa hegemônica, permitem a contraposição de projetos de cidade e podem alavancar mudanças espaciais.

A prática espacial é a categoria que completa a tríade conceitual da teoria da produção do espaço, remetendo aos espaços percebidos, que são observáveis diretamente na vida cotidiana. A análise aqui recai nas rotinas dos habitantes da cidade associadas às ligações e separações entre os lugares próprios a determinada realidade urbana. Desta forma, cada sociedade possui uma prática espacial que pressupõe e produz o espaço a partir de intervenções materiais e corporais.

Ao analisar a produção do espaço, Lefebvre (1974) afirma que, nas sociedades capitalistas, "valores de troca" tendem a se sobrepor a "valores de uso", o que confere ao espaço urbano um sentido de "mercadoria" facilmente reproduzível mais do que de "obra de arte", algo único e insubstituível. O balanço de qualidades apresentado pelo espaço urbano produzido diferencia a obra de arte da mercadoria. Se valores de uso são encorajados, tais como o encontro, a centralidade e a convergência de diferenças, então resultam do processo produtivo espaços que propiciam condições para o florescimento de comunidades humanas criativas. Porém, se valores de troca são priorizados, esses espaços acabam por se tornar meros produtos instrumentalizados para a acumulação de capital.

A priorização dos valores de troca em detrimento dos valores de uso tende a afetar a diversidade da prática espacial, romper os laços dos habitantes com a urbe e desencadear lutas sociais pelo direito à cidade (LEFEBVRE, 1968). Em que pese o pioneirismo de Lefebvre na reflexão sobre o direito à cidade como direito humano e a especificidade das lutas dos movimentos sociais urbanos, há que se reconhecer que, em larga medida, a teoria da produção do espaço negligencia a análise da dimensão jurídica deste processo. Por isso, funciona melhor enquanto instrumental teórico se articulada com uma teoria sobre a regulação jurídica do espaço.

\section{A teoria da regulação do espaço}

Considerando que também as normas jurídicas podem ser entendidas enquanto um conjunto de representações do espaço (BUTLER, 2009, p. 322), a geografia jurídica tem investigado a sua incidência sobre as configurações espaciais. Parte-se da premissa de que há uma luta social em torno do espaço, o que implica problematizar "quem o possui, quem o controla, quem tem o 
direito de estar nele, e o que se pode ou não fazer uma vez nele" (MITCHELL, 2003, p. 46, tradução nossa). Isso exige examinar o conteúdo de relações sociais de propriedade (AZUELA, 1989) que se apresentam em constante transformação (BLOMLEY, 2004; STAEHELI; MITCHELL, 2008).

Com base nesses pressupostos, teorias vêm sendo construídas na geografia jurídica para explicar como os espaços urbanos são regulados. Segundo a proposta de Konzen, três categorias são úteis para teorizar as variações na regulação do espaço: "espaços jurisdicionais", "zonificação espacial" e "espaços territoriais" (2013, p. 269 e ss.).

Os espaços jurisdicionais remetem à espacialidade das normas jurídicas. Esses enunciados normativos, reproduzidas no campo jurídico, constituem limites espaciais bastante precisos, criados por instituições governamentais para fins de elaboração e execução de determinadas políticas. Assim, os espaços jurisdicionais definem o alcance espacial das normas jurídicas que orientam os comportamentos. ${ }^{13}$

A categoria zonificação espacial diz respeito às práticas jurídicas, correspondendo a uma espacialidade definida em termos narrativos e por meio de marcos espaciais concretos, de maneira mais imprecisa, flexível e discricionária. Os agentes da administração pública são oficialmente autorizados a fazer uso de meios coercitivos, isto é, do poder de polícia administrativa, a fim de obter o cumprimento das normas jurídicas. No entanto, a depender do lugar em que se esteja na cidade, a sua atuação tende a variar, ou até mesmo inexistir. ${ }^{14}$

Já os espaços territoriais correspondem à espacialidade das normas sociais, que são definidas de modo concreto, fluido e por vezes efêmero. Esses enunciados normativos não são reproduzidos no interior do campo jurídico, mas operam cotidianamente enquanto ferramenta de coesão interna de comunidades com vínculos de proximidade. Assim, regulam as relações entre seus membros e distinguem quem pertence e quem não pertence socialmente a determinado espaço urbano. ${ }^{15}$

Ao investigar empiricamente a regulação dos espaços públicos urbanos, Konzen (2013) sustenta que as normas jurídicas, as práticas jurídicas e as normas sociais são fortemente influenciadas por determinadas representações do espaço. Por isso, as diferenças na regulação jurídica dos espaços públicos de uma mesma cidade tendem a se aprofundar. As instituições e os agentes estatais, ao controlarem o público nos espaços públicos, podem encorajar práticas espaciais de certos grupos sociais em detrimento de outros em uma determinada zona da cidade, o que no limite pode pôr em xeque o caráter público desses lugares. Por sua vez, ao alocarem recursos financeiros e não financeiros com prioridade para determinada zona da cidade em desfavor das demais, instituições e os agentes estatais podem alimentar desequilíbrios de 
atratividade entre os espaços públicos, tornando igualmente questionável o caráter público dos lugares relegados a um segundo plano. Disso resultam padrões de desenvolvimento urbano desigual e injustiças espaciais nas metrópoles, que tendem a ser contestados pelos movimentos sociais que lutam pelo direito à cidade.

Essas categorias teóricas do campo da geografia jurídica serão utilizadas, a seguir, para analisar o caso do Cais Mauá, a fim de contribuir para a compreensão das mudanças na regulação dos espaços públicos relacionadas à revitalização urbana de áreas portuárias.

\section{O CASO DA REVITALIZAÇÃO DO CAIS MAUÁ}

A área do Cais Mauá ultrapassa os 180 mil metros quadrados e estende-se ao longo da orla do Guaíba no trecho localizado entre a Estação Rodoviária e a Usina do Gasômetro, junto ao Centro Histórico de Porto Alegre. A sua centralidade na realidade urbana da cidade, histórica e simbolicamente, também envolve o lugar que ocupa na identidade e no imaginário de seus habitantes. Idealizadas e executadas entre as décadas de 1890 e 1930, as instalações portuárias são uma das principais obras públicas realizadas na cidade durante a Primeira República, período em que Porto Alegre despontava como centro comercial e industrial. No seu auge, a área portuária era a "porta de entrada" da cidade, movimentando dezenas de milhares de embarcações anualmente. Suas docas e armazéns, integrados às ruas centrais e, abasteciam a população com toda sorte de mercadorias. $^{16}$

Planejada após uma grande enchente ocorrida em 1941 e concluída somente nos anos 1970, a construção do Muro da Mauá, com 2.600 metros de extensão, acabou por isolar o Cais Mauá do restante do Centro Histórico. No decorrer das décadas seguintes, as instalações portuárias restaram obsoletas, sendo as atividades ali desenvolvidas paulatinamente desativadas ou transferidas para áreas contíguas, como o Cais Navegantes e o Cais Marcílio Dias. Ao mesmo tempo, de maneira cada vez mais frequente, passou-se a utilizar a área para a realização de feiras, exposições e outros eventos de cunho cultural. Na década de 1990, já era recorrente no imaginário de grande parte da população a ideia de que Porto Alegre crescera "de costas para o Guaíba". Nesse período, despontavam no exterior os projetos de revitalização urbana de áreas portuárias, ao mesmo tempo em que aumentavam os clamores por parte da elite globalizada da cidade pela reprodução dessas inciativas.

Em uma aproximação retrospectiva ao conflito urbano envolvendo a revitalização deste lugar emblemático da capital gaúcha, é possível identificar ao menos duas fases principais: o período de quase duas décadas em que se consolida a decisão política de revitalizar a área 
portuária, levando à aprovação de um projeto oficial de revitalização urbana, em 2010; e o período que se estende de 2011 até 2019, em que a implementação da revitalização do Cais Mauá pela empresa arrendatária pouco avança, em meio ao recrudescimento de movimentos de contestação política e jurídica ao projeto, suscitando um impasse que culmina na rescisão do contrato pelo Governo do Estado.

\section{O projeto oficial de revitalização}

Inicialmente idealizados pela administração pública municipal de Porto Alegre, os primeiros planos oficiais de intervenção no Cais Mauá foram propostos no final da década de 1980. A partir de meados dos anos 1990, houve um deslocamento do protagonismo da Prefeitura Municipal para o Governo do Estado, que assumiu as atividades portuárias delegadas pela União. Desde então, todos os chefes do executivo estadual manifestaram, a despeito das diferenças político-partidárias, o interesse do governo em revitalizar o Cais Mauá, instituindo comissões com a finalidade de realizar estudos e propor alternativas de usos do espaço. ${ }^{17}$ Com o encerramento das operações portuárias, em 2005, esses trabalhos ganharam impulso, e foram acelerados em 2007, com a expectativa de que Porto Alegre viesse a ser escolhida como uma das cidades-sede da Copa do Mundo de Futebol de 2014, já que o megaevento era visto por lideranças políticas e empresariais como uma janela de oportunidade para promover intervenções urbanas que não poderia ser desperdiçada.

O processo de concepção do projeto oficial de revitalização foi desencadeado pelo Decreto Estadual n. 45.187, de 27 de julho de 2007, que instituiu uma Comissão Técnica, formada por representantes do Estado do Rio Grande do Sul e do Município de Porto Alegre, com a incumbência de selecionar e avaliar estudos sobre a revitalização do Cais Mauá. O Decreto também abriu prazo para Manifestação de Interesse, isto é, a apresentação pela iniciativa privada de estudos de caráter técnico, econômico-financeiro e jurídico que pudessem subsidiar a contratação de um projeto de revitalização urbana pelo governo, considerando uma série de objetivos:

O Projeto de Revitalização do Cais Mauá terá como objetivo a integração da cidade ao porto, com a recuperação e modernização de áreas, inclusive as tombadas, dotadas de relevante valor histórico, paisagístico e cultural, do Estado do Rio Grande do Sul. O objetivo do projeto é dar utilidade aos bens integrantes da área do Cais Mauá, que serão destinados a atividades institucionais do Estado, bem como a atividades de cultura, lazer, turismo e empresarial (ESTADO DO RIO GRANDE DO SUL, 2007).

Em maio de 2009, o Governo do Estado entregou à Prefeitura de Porto Alegre o resultado do trabalho da Comissão Técnica, elaborado com base no material apresentado pelo consórcio 
vencedor. ${ }^{18}$ Para fins de planejamento da intervenção, a área do Cais Mauá foi dividida em três setores distribuídos ao longo da orla do Guaíba (Tabela 1 e Figura 1).

Tabela 1 - Setorização do Cais Mauá

\begin{tabular}{|l|l|l|}
\hline Setores & Descrição da área & Extensão \\
\hline Gasômetro & $\begin{array}{l}\text { Área localizada no final da Av. Mauá, em frente à Praça } \\
\text { Brigadeiro Sampaio e ao lado da Usina do Gasômetro. }\end{array}$ & 41.500 \\
\hline Armazéns & $\begin{array}{l}\text { Área localizada paralelamente à Av. Mauá, do Mercado } \\
\text { Público até a Praça Brigadeiro Sampaio. Possui antigos } \\
\text { armazéns protegidos legalmente como patrimônio }\end{array}$ & 74.000 \\
& $\begin{array}{l}\text { Árstórico. } \\
\text { Área localizada paralelamente à Av. Mauá, entre a } \\
\text { Rodoviária e o Mercado Público. Encontram-se nesta } \\
\text { área, onde estão as docas de atracação do antigo porto, } \\
\text { galpões utilizados como depósito da Superintendência } \\
\text { dos Portos e Hidrovias, Bombeiros e um antigo }\end{array}$ & 65.600 \\
\hline
\end{tabular}

Fonte: Estado do Rio Grande do Sul (2010)

Figura 1 - Setorização do Cais Mauá

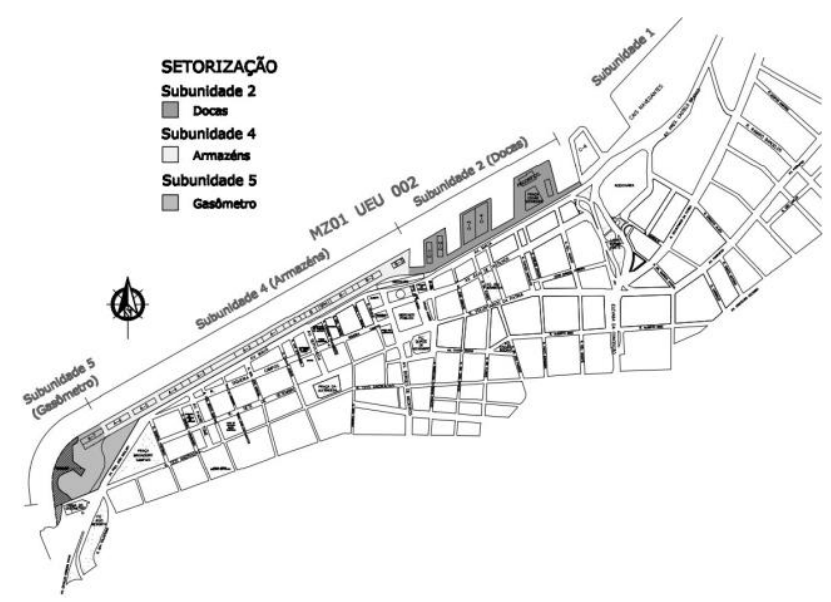

Fonte: Porto Alegre (2010)

Em síntese, a proposta concebia o Cais Mauá como um complexo voltado a atividades de turismo, comércio e negócios, a ser dotado de uma identidade comum enquanto empreendimento 
empresarial. No setor Gasômetro, seria construído um shopping center. No setor Armazéns, os antigos galpões tombados como patrimônio histórico seriam restaurados e abrigariam lojas, bares e restaurantes com vista para as águas do Guaíba; no setor Docas, as construções existentes seriam demolidas e dariam lugar a torres comerciais para abrigar escritórios, um hotel de luxo e um centro de eventos.

Também foram divulgados pela Comissão Técnica uma proposta de projeto de lei municipal estabelecendo um novo regime urbanístico para a área do Cais Mauá e uma proposta de diretrizes básicas para um edital de arrendamento oneroso dos bens públicos que compunham a área. Estavam lançados, assim, os alicerces do projeto oficial de revitalização, que pressupunha a sua exploração pela iniciativa privada.

De maneira geral, as alterações aprovadas na legislação municipal seguiram a proposta da Comissão Técnica. Foram feitos ajustes no Plano Diretor de Desenvolvimento Urbano Ambiental de Porto Alegre (PPDUA), incluindo o Cais Mauá no rol de Áreas de Revitalização. Nos termos do art. 83, IV, do PPDUA, a área deveria ser objeto de projetos e planos específicos, que pudessem transformá-la em "polo de atração e irradiação de desenvolvimento científico, tecnológico, cultural, artístico, turístico, educacional, de inovação, de novos negócios e de desenvolvimento socioeconômico [...]" (PORTO ALEGRE, 2011). Foi também aprovada a Lei Complementar n. 638/2010, conhecida como Lei de Usos para o Cais Mauá, modificando o regime urbanístico (atividades, densidades, índices de aproveitamento, alturas, taxas de ocupação etc.). ${ }^{19}$ Ficaram expressamente vedados o uso residencial e a instalação de templos religiosos (art. 13); outros usos foram encorajados, ainda que de modo vago, como atividades de educação ambiental, cultura e artesanato, incubação de empresas de base tecnológica e utilização da área por embarcações de passeio e transporte hidroviário coletivo (arts. 2으, 3으 e 5으). Também foram traçadas estratégias para a urbanização da área (arts. 60 e 7º), como edificações ambientalmente sustentáveis, instalação de ciclovias e conexão com os espaços adjacentes do Centro Histórico (PORTO ALEGRE, 2010).

O Edital de Concorrência Internacional n. 01/2010, lançado pelo governo do Estado do Rio Grande do Sul, também seguiu a proposta elaborada pela Comissão Técnica. O documento informava aos licitantes que

as Propostas já apresentadas quando da Manifestação de Interesse, as quais ensejaram os Estudos de Viabilidade Econômica disponibilizados a todos os interessados nesta Licitação, devem ser consideradas como indicativos e não impositivos. Cogentes são os Regimes Urbanísticos e os Limitantes da Lei Complementar Municipal $n^{\circ} 638 / 10$ e as exigências constantes destes Termos de Referência e do Edital de Licitação. É evidente que "o mix" de opções comerciais avaliado na "Manifestação de Interesse" configurou-se de 
grande valor social e econômico para o Estado, e a diversidade de opções e a qualidade das mesmas continuará a ser fator preponderante na definição da melhor Proposta (ESTADO DO RIO GRANDE DO SUL, 2010, p. 49).

Cabe referir que, a partir da publicação do edital do certame licitatório, informações mais concretas acerca do projeto oficial de revitalização do Cais Mauá foram tornadas públicas. 0 contrato administrativo de arrendamento oneroso seria celebrado com duração de 25 anos (prorrogáveis uma vez, por igual período). O arrendatário assumiria o compromisso com a realização de investimentos em obras e instalações necessárias à implementação da revitalização urbana, no montante mínimo de 350 milhões de reais. Seria declarada vencedora a proposta que oferecesse o maior "valor anual do arrendamento", fixando-se o valor mínimo em 1,2 milhões de reais por ano (ESTADO DO RIO GRANDE DO SUL, 2010). Em contrapartida, a remuneração do arrendatário adviria da exploração comercial do Cais Mauá, isto é, das receitas auferidas por meio da prestação de serviços de entretenimento, lazer, cultura, turismo e negócios aos usuários, seja diretamente, seja mediante contratação com terceiros (ESTADO DO RIO GRANDE DO SUL, 2010, p. 12).

Publicado o edital, a empresa Cais Mauá do Brasil S.A. foi a única a apresentar proposta, tornando-se vencedora do certame, com investimento total previsto entre 400 e 500 milhões de reais e oferta ao Governo do Estado do valor de 2,5 milhões de reais anuais pelo arrendamento (DIÁRIO OFICIAL DE PORTO ALEGRE, 2010, p. 1). Quanto ao projeto para a área, a proposta vencedora reproduziu em grande medida o conteúdo do material selecionado por ocasião da Manifestação de Interesse (Figura 2). Embora a proposta apresentada pelo consórcio indicasse a intenção de se combinar espaços públicos e privados, as áreas designadas como espaços públicos praticamente se limitavam à frente longitudinal do empreendimento e aos pontos de interseção entre os armazéns. ${ }^{20}$

A solenidade da assinatura do contrato de arrendamento com a Cais Mauá do Brasil S.A. ocorreu em dezembro de 2010, em clima festivo. Na ocasião, a Governadora do Estado declarou: "Quando estiver revitalizado, o Cais Mauá será, além de cartão-postal, forte promotor do desenvolvimento e do turismo do Rio Grande do Sul” (DIÁRIO OFICIAL DE PORTO ALEGRE, 2010, p. 1); ao que o então Prefeito Municipal acrescentou: "Todos sabem da importância deste momento, de um porto inoperante e sendo um dos locais mais bonitos da cidade. Será uma referência de Porto Alegre para o mundo na Copa de 2014 e depois desse evento" (DIÁRIO OFICIAL DE PORTO ALEGRE, 2010, p. 1). 
Figura 2 - Imagem do projeto vencedor - Centro comercial no setor Gasômetro

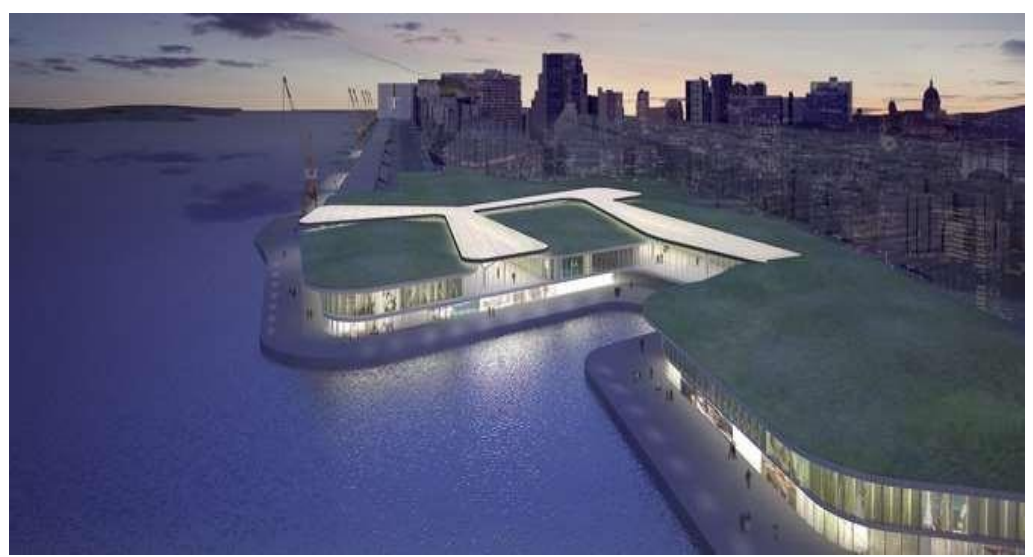

Fonte: Cais Mauá do Brasil S.A (s/d).

Disponível em: <http://vivacaismaua.com.br/galeria-de-fotos/>. Acesso em: 02 mar. 2020.

A partir do que foi exposto, percebe-se que o projeto oficial de revitalização do Cais Mauá corresponde a uma representação do espaço, compartilhada tanto pelos empreendedores quanto pelas principais autoridades locais. Se analisado o processo desde seu início, fica difícil distinguir entre as propostas dos grupos empresariais - apresentadas nos estudos prévios submetidos à Comissão Técnica e consolidadas posteriormente na proposta vencedora do certame licitatório - e as da administração pública, que foram veiculadas por meio da Lei de Usos para o Cais Mauá e do Edital de Concorrência Internacional. Da análise da documentação do processo depreende-se que, ao invés de fixarem balizas para o empreendedorismo privado tendo em vista os interesses de diferentes grupos sociais, a legislação municipal e o edital de licitação seguiram as diretrizes fixadas anteriormente pelo próprio parceiro empresarial. Desta maneira, são evidentes os limites de uma parceria entre o poder público e a iniciativa privada que faz com que se confundam os interesses de atores sociais que, por princípio, deveriam seguir lógicas distintas. ${ }^{21}$

Além disso, as intervenções previstas no projeto oficial de revitalização - notadamente, a construção do shopping center e das torres comerciais - sugerem uma priorização do valor de troca do espaço em detrimento de seu valor de uso. No caso do Cais Mauá, a representação do espaço concebida enfatiza as possibilidades de exploração dos usos econômicos da área para fins turísticos, comerciais e de negócios, inclusive no que se refere ao patrimônio cultural existente. Da mesma forma, os discursos técnicos salientam as possibilidades de geração de renda, seja por meio da criação de oportunidades de trabalho na construção e operação do empreendimento, seja por meio da geração de recursos financeiros advindos de um melhor posicionamento de Porto Alegre nos 
circuitos turísticos. Tal representação do espaço, todavia, não se revelaria tão harmônica e consensual.

\section{Os movimentos de contestação}

A partir de 2011, foi posto em marcha o complexo processo de licenciamento urbanístico e ambiental do empreendimento, que incluiria a realização do Estudo de Impacto Ambiental (EIARIMA) e do Estudo de Viabilidade Urbanística (EVU). Com efeito, após uma tramitação longa e controversa, somente em dezembro 2017 foi emitida a Licença de Instalação para a Cais Mauá do Brasil S.A., autorizando o início das obras de execução do projeto (MUNICÍPIO, 2017). Nesse ínterim, em meio a denúncias de irregularidades no certame licitatório, problemas na obtenção das licenças necessárias, dificuldades financeiras por parte da empresa arrendatária e mudanças diversas em sua estrutura acionária, surgiu um fato novo: a articulação de movimentos de contestação.

Notadamente a partir de 2014, dois grupos principais se articularam, o “Ocupa Cais Mauá" e o "Cais Mauá de Todos". ${ }^{22}$ Esses movimentos de contestação mobilizavam estudantes, moradores do Centro Histórico e pessoas oriundas de diversas entidades e coletivos locais. As primeiras manifestações desses grupos de ativistas tiveram como temas comuns a denúncia da falta de diálogo com a população na concepção do projeto de revitalização e a percepção de que a proposta levaria à "elitização", "mercantilização" e mesmo à "privatização" do Cais Mauá, um lugar icônico da cidade. Na percepção dessas pessoas, o Cais Mauá havia sido concebido no projeto de revitalização como um lugar destinado prioritariamente a um público de turistas e residentes das classes mais abastadas.

Por meio de variadas estratégias de ativismo, como a promoção de palestras, a criação de páginas em redes sociais, a redação de abaixo-assinados, a realização de intervenções artísticas e até mesmo a proposição de ações judiciais, os movimentos de contestação ao projeto de revitalização deflagraram uma disputa em torno do Cais Mauá. Nesse período, foi marcante a materialização dos discursos de contestação através de uma infinidade de artefatos físicos e virtuais - panfletos, cartazes, fotografias e vídeos - espalhados pelas ruas e pela internet. Por exemplo, uma carta aberta postada em uma rede social pelo Movimento Ocupa Cais Mauá declarava:

[...] A participação popular nas decisões que transformam o espaço urbano é um direito garantido em nossa Constituição. Desde o início do processo de remodelação do Cais Mauá, a população de Porto Alegre não teve este direito respeitado. Em 2010 o governo estadual [...] abriu licitação para uma parceria público-privada com a intenção de remodelar o porto, sem realizar qualquer tipo de consulta aos cidadãos. [...] O projeto ficou a cargo do consórcio vencedor de capital estrangeiro (que se denominou Cais Mauá do Brasil S.A.). 
A partir disto o consórcio decidiu, de acordo com seus interesses, quais seriam as diretrizes de uso do espaço (mais uma vez sem participação popular, atitude esperada quando se delega à iniciativa privada as decisões sobre o que é público). [...] nos opomos frontalmente a esse modelo autoritário de revitalização urbana, com a mesma veemência que combatemos qualquer forma de abandono ou subutilização do nosso Cais Mauá. Acreditamos que este processo deve considerar as vozes que vêm de diferentes regiões da cidade e deve ser construído sobre princípios como diversidade, inclusão, bem como valorização e respeito ao patrimônio histórico, cultural, social e ambiental [...] (OCUPA CAIS MAUÁ, 2014).

Os movimentos de contestação, ao reivindicarem a efetiva participação popular no processo decisório, trouxeram à tona uma demanda que ultrapassava a inconformidade em relação ao conteúdo do projeto oficial de revitalização. Em uma postagem pública em uma rede social, o movimento Cais Mauá de Todos afirmava:

[...] A Parceria Público Privada pode ser bem-vinda, desde que regulada pelo Estado em prol do interesse público. E garantidas a ampla participação, total transparência e plena legalidade do processo; para que a população decida, de fato e de direito, qual a melhor forma de requalificação do Cais Mauá [...] Falsas polêmicas "favoráveis X contrários", "vanguarda X atraso", "realistas X românticos" desrespeitam a inteligência de milhões de gaúchos. Todos somos favoráveis à revitalização do Cais. A discussão é sobre QUAL "revitalização" é boa para a sociedade e para a memória da cidade que se construiu a partir do Cais do Porto. [...] Toda a população quer o Cais Mauá reintegrado ao Centro Histórico! E exigimos participação, transparência e legalidade em todo o processo porque é sempre bom lembrar que a cidade não pertence apenas ao prefeito e aos vereadores, pertence a todos os portoalegrenses. Defendemos a imediata: 1) Rescisão de contrato do Consórcio Cais Mauá S.A, 2) Participação popular e ouvida da sociedade civil; 3) Abertura de concurso público de projetos e 4) Realização de nova licitação [...] (CAIS MAUÁ DE TODOS, 2015).

No entanto, talvez a mais emblemática estratégia de contestação utilizada por esses movimentos tenha sido a organização de atos de ocupação no Cais Mauá (Figura 3). Em várias ocasiões, por meio de "eventos públicos" criados em uma rede social, a população foi convocada a ocupar a área portuária. Centenas de pessoas, de variadas faixas etárias e grupos sociais, ainda que com a predominância de um público universitário, participaram desses eventos. Geralmente iniciando a partir do período da tarde e adentrando a noite, de forma a envolver em sua programação a possibilidade de se desfrutar do pôr do sol no Guaíba, os atos converteram o espaço urbano ocupado em lugar de encontro para múltiplas atividades: conversas entre amigos, shows de bandas de rock, rodas de violão, performances artísticas, venda ambulante de mercadorias e, claro, discussões sobre a cidade. Os atos de ocupação possibilitavam que diversas pessoas 
pudessem perceber o lugar enquanto espaço público, aberto a uma ampla gama de usos programados e não programados.

Figura 3 - Ato de ocupação no Cais Mauá

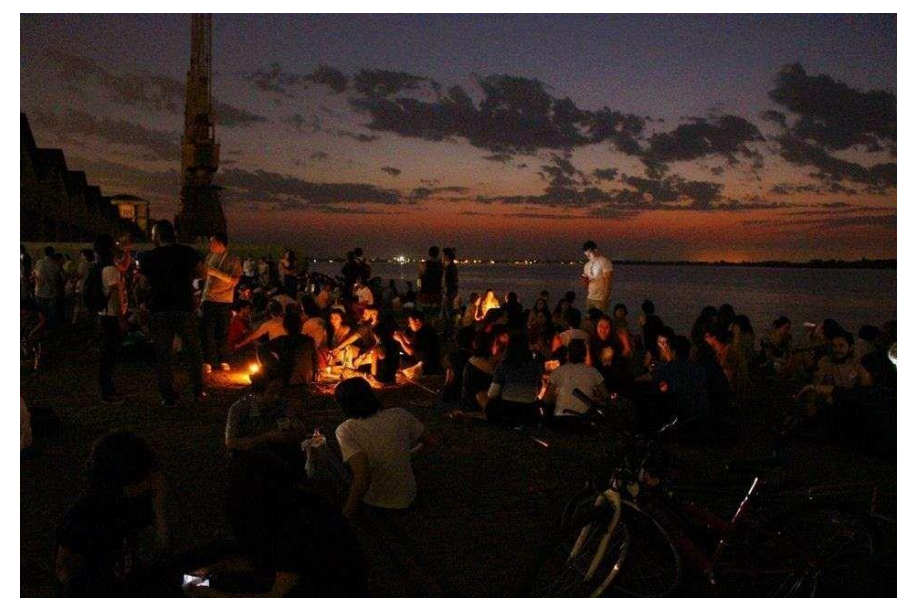

Fonte: Ocupa Cais Mauá, 2014.

Disponível em: <https://www.facebook.com/ocupacaismaua/>. Acesso em: 02 mar. 2020.

As reações aos atos de ocupação do Cais Mauá, entretanto, não tardaram a ocorrer. Assim que passou a exercer efetivamente a posse da área, em 2014, a Cais Mauá do Brasil S.A. publicou o seguinte comunicado:

A Cais Mauá do Brasil S.A. comunica que, durante o período de execução das obras de revitalização, visando proteger os frequentadores, está proibida a permanência de pessoas não autorizadas no interior do Complexo para visitação. Somente está autorizada a passagem de usuários dos serviços de transporte público e demais serviços náuticos prestados no Complexo, através do acesso do Mercado Público. Assim, a empresa proíbe, não reconhece, não consente e não se responsabiliza por quaisquer eventos e/ou movimentos realizados nas dependências do Complexo, uma vez que a área não tem as autorizações nem as estruturas necessárias para permitir a realização de eventuais eventos e/ou movimentos com segurança. A área do Cais Mauá está sem iluminação adequada, com buracos e ferros expostos caracterizando-se como uma zona de perigo (CAIS MAUÁ DO BRASIL S.A., 2014).

Assim, em razão de todos os acessos terem sido bloqueados por agentes de segurança contratados pela empresa arrendatária, os atos de ocupação passaram a ocorrer em espaços públicos situados no entorno do local. À época, compartilhava-se em alguma medida a percepção de que a interdição a certas práticas sociais no Cais Mauá não se tratava de uma diligência de caráter passageiro; ao contrário, temia-se que determinadas atividades permanecessem vedadas mesmo após o término da execução das obras de revitalização. Nesse sentido, o ato de "ocupar" 
contribuía para a ressignificação do espaço, potencializando imaginários e usos alternativos às representações do espaço. Os atos de ocupação indicavam variadas formas de se usar um espaço, traduzindo possibilidades alternativas de regulação para o espaço público enquanto potencial lugar de encontro das diferenças.

Os resultados de tamanha mobilização ficaram evidentes em 2015, durante a realização de uma audiência pública para fins de debate do EIA-RIMA com a população de Porto Alegre. Em que pese tenha sido realizado em um clube desportivo localizado em um bairro relativamente distante do Centro Histórico, o evento contou com a participação de centenas de pessoas que apresentaram aos representantes do poder público e da Cais Mauá do Brasil S.A. suas inquietações acerca do projeto de revitalização. A imprensa local registrou os pronunciamentos do público presente: alguns apoiadores da proposta bradavam "privatiza tudo!", enquanto "espaço público não é mercadoria!" eram as palavras de ordem da maioria (EM AUDIÊNCIA, 2015; TUMULTO, 2015).

Os movimentos de contestação, todavia, não elaboraram uma proposta de revitalização pronta e acabada para o Cais Mauá, em contraposição ao projeto oficial de revitalização. Ao invés de oferecerem um projeto alternativo, os movimentos de contestação contribuíram para o processo de produção social do espaço chamando a atenção da população, do poder público e dos empreendedores privados para a existência de divergências quanto às escolhas a serem feitas, inscrevendo na realidade espacial seus espaços de representação e suas práticas espaciais e reivindicando o direito à cidade. ${ }^{23}$

Ao que tudo indica, a decisão política tomada em maio de 2019 pelo Governo do Estado (GOVERNO, 2019), com base em parecer da Procuradoria-Geral do Estado (PGE-RS), sepultou o projeto de revitalização urbano aprovado em 2010. ${ }^{24}$ Avaliar em que medida os movimentos de contestação contribuíram para a rescisão unilateral do contrato de arrendamento com a empresa Cais Mauá do Brasil S.A. é tarefa difícil. Mas os movimentos de contestação demonstraram, ao longo dos últimos anos, que a sua inconformidade com o projeto de revitalização passava pelo questionamento da regulação jurídica aplicável à área e sua repercussão para a redução ou ampliação do público e dos usos potenciais do espaço.

Ao mesmo tempo, sabe-se que o encerramento do contrato de arrendamento não significou o fim do conflito envolvendo a revitalização urbana do Cais Mauá. Notícias recentes apontam para a possibilidade de um aprofundamento da disputa estabelecida em torno do espaço, especialmente se consideradas as manifestações do executivo estadual, que pleiteia junto à União a extinção da área de porto organizado e estuda a viabilidade de alienação dos imóveis que a 
integram (QUEREMOS, 2019). Diante desse cenário, cabe examinar quais seriam as possíveis implicações do projeto em termos de mudanças na regulação jurídica dos usos do Cais Mauá.

\section{OS IMPACTOS DAS MUDANÇAS NA REGULAÇÃO DO CAIS MAUÁ}

A interpretação dos resultados da pesquisa empírica à luz das categorias teóricas da geografia jurídica revela que as mudanças de regulação do Cais Mauá tendem a resultar na separação entre a área portuária e o entorno no que se refere às normas e práticas jurídicas aplicáveis, isto é, na conformação de um espaço jurisdicional. Por outro lado, como se verá, as representações do espaço concebidas também estão atreladas ao desenvolvimento de mecanismos de controle seletivo do público e de promoção desigual de usos públicos.

\section{A conformação de um espaço jurisdicional}

As disputas em torno do projeto de revitalização inequivocamente inauguraram um produtivo debate acerca da abertura a uma gama diversificada de usos públicos de um espaço urbano antes destinado quase que exclusivamente às atividades portuárias. Mas o projeto também significou a reconfiguração de um espaço jurisdicional bem delimitado, qual seja, a área do porto organizado, um imóvel público federal cuja gestão até então estava delegada ao governo estadual.

No caso estudado, apostou-se na viabilização da revitalização urbana do Cais Mauá por meio do arrendamento oneroso de bens do patrimônio público para exploração comercial por uma empresa privada. A expectativa era de que a organização empresarial contratada por meio de certame licitatório assumisse a responsabilidade pela gestão da área do porto organizado por um período que poderia se estender por até 50 anos. Isto é, a tendência seria a de que, no imaginário de gerações de porto-alegrenses, o Cais Mauá viesse a ser visto como um empreendimento pertencente a uma empresa privada - seguindo, portanto, a lógica aplicável a um espaço privado aberto ao público, em que se admite a exclusão de certos usos e públicos indesejados.

A legislação municipal e o contrato de arrendamento impuseram limites um tanto frágeis diante da ampla margem de discricionariedade que foi concedida à empresa arrendatária para criar e fazer cumprir normas relativas ao uso deste espaço urbano. Na prática, era provável que, assim que o Cais Mauá fosse reinaugurado, viessem a ser estabelecidas normas pela empresa responsável pela sua manutenção e administração com o propósito de determinar quem poderia e quem não poderia usufruir daquele espaço, isto é, quem poderia adentrar em certos lugares e quem não estaria autorizado a fazê-lo, quais práticas poderiam ser realizadas ali e quais não poderiam, quais intervenções seriam permitidas e quais seriam proibidas, e assim por diante. 
Ainda que o instrumento jurídico escolhido pelo poder público não implicasse na transferência da propriedade dos imóveis para a iniciativa privada, a criação deste espaço jurisdicional mostrava-se pertinente para o propósito específico de projetar espacialmente um conjunto específico de normas jurídicas voltadas a regular o uso desta área da cidade em separado, isto é, normas de conteúdo diferente das aplicáveis aos espaços públicos do seu entorno, como as ruas e praças do Centro Histórico de Porto Alegre. Paradoxalmente, a regulação nesse espaço jurisdicional poderia em muito se assemelhar àquela existente em empreendimentos turísticos similares existentes em outras tantas cidades ao redor do mundo.

Assim, quando se pensa em algumas práticas cotidianas e comuns no Centro Histórico de Porto Alegre, como a venda ambulante, as performances artísticas, os protestos e manifestações políticas, não é possível afirmar com segurança se seriam ou não possíveis de serem realizadas no espaço revitalizado, já que tanto a legislação municipal que regulamenta os usos da área do Cais Mauá quanto o contrato de arrendamento não abordavam esses aspectos. Ao fim e ao cabo, ainda que não tenha sido efetivada a transferência da propriedade, com a cessão onerosa da posse do terreno ocorreu a conformação de um espaço jurisdicional em relação ao qual os poderes de gestão e regulação passaram a ser exercidos, em grande medida, por uma empresa privada.

\section{O controle seletivo do público e a promoção desigual de usos}

O caso do Cais Mauá não pode ser analisado de maneira dissociada do que se passa no conjunto de Porto Alegre. No projeto de revitalização, o espaço foi desde o princípio concebido como uma atração da zona turística de Porto Alegre que, como tal, estaria sujeita a uma regulação diferenciada em relação ao restante da cidade. Conforme já visto, essas diferenças em termos de regulação do espaço podem surgir na medida em que o controle do público é exercido por meio de mecanismos que desencorajam as práticas espaciais de certos grupos sociais, privilegiando públicos e usos mais rentáveis economicamente; e também na medida em que se confere prioridade à zona turística no que se refere à alocação de recursos voltados à promoção de usos públicos.

As estratégias que podem vir a ser adotadas para fins de controle seletivo do público são bastante conhecidas pela população da cidade, já habituada ao modelo de funcionamento dos shopping centers, por exemplo. A exclusão de certos públicos e usos indesejados pode ser viabilizada mediante barreiras físicas como portões, cercas, grades e muros - sintomaticamente, o projeto de revitalização não previa a demolição do Muro da Mauá ou outra solução adequada para integrar fisicamente a área portuária às ruas do Centro Histórico - combinadas com a utilização de câmeras de vigilância e o emprego de uma força de segurança privada. Tipicamente, esses 
mecanismos estão atrelados a normas de conduta específicas sobre aspectos como horários de funcionamento, vestimentas aceitáveis, porte de artefatos etc. passíveis de serem criadas pelos gestores do espaço e aplicadas na forma de sanções a eventuais transgressores.

Os elementos destacados, de certa maneira, indicam que, no caso do projeto de revitalização do Cais Mauá, o caráter público do espaço urbano em produção é, no mínimo, duvidoso na perspectiva de determinados atores sociais. Afinal, se os espaços públicos são lugares que favorecem o encontro de públicos diversos e incentivam a convivência de comportamentos concorrentes, conflitantes, e inclusive harmoniosos, então a efetiva realização dessa multifacetada função requer certa desordem e imprevisibilidade, ao invés de um controle rigoroso e uma homogeneização das atividades.

A prioridade à zona turística da cidade no que se refere à alocação de recursos voltados à promoção de usos públicos revela-se justamente no instrumento jurídico escolhido para promover o processo de revitalização urbana do Cais Mauá. Com base em "estudos técnicos, econômicofinanceiros e jurídicos" elaborados pelas próprias empresas interessadas em sua exploração econômica, a administração pública optou pela utilização de um contrato de arrendamento. Ocorre que o objeto desse contrato de arrendamento forçosamente restringe-se aos bens públicos integrantes da área do porto organizado, aos quais deverão ser direcionados os investimentos previstos no projeto de revitalização urbana. Tal escolha foi feita em detrimento da utilização estratégica na política urbana pela Prefeitura Municipal de ferramentas jurídico-urbanísticas que envolvessem intervenções integradas na região do Centro Histórico, abarcando outros imóveis de titularidade pública e privada não utilizados ou subutilizados. É de se questionar se uma distribuição mais justa dos benefícios e ônus decorrentes do processo de urbanização, como apregoa o Estatuto da Cidade, pode ser de alguma forma alcançada com um projeto restrito à área do porto organizado.

O projeto de revitalização do Cais Mauá ilustra a tendência de criação de mecanismos normativos de controle seletivo do público e promoção desigual de usos públicos, atrelados às representações espaciais que enfatizam a exploração econômica da área para fins de turismo, comércio e negócios. Este estudo de caso também mostra que nem sempre as instituições estatais e seus agentes desempenham, diretamente, as funções de controlar o público e promover usos públicos. Por vezes, a responsabilidade por sua execução é transferida pelo Estado a outros atores sociais que não integram a sua estrutura, como empresas privadas, tal qual sucedeu no caso em análise. 


\section{CONSIDERAÇÕES FINAIS}

Por meio do estudo do caso do Cais Mauá, discutiu-se neste artigo a dimensão jurídica dos projetos de revitalização urbana de áreas portuárias. A partir da elaboração de um projeto de revitalização deste espaço urbano icônico de Porto Alegre pelo governo estadual em estreita colaboração com a iniciativa privada, criou-se a expectativa de abertura a um considerável leque de usos públicos de um espaço urbano até então subutilizado, o que resultaria em uma mudança substancial de sua função social na cidade. O problema de pesquisa era saber o que as disputas sociais em torno do projeto de revitalização significavam em termos de possíveis mudanças na regulação jurídica dos usos desse espaço urbano.

Concluiu-se que os processos de revitalização urbana de áreas portuárias significam substanciais mudanças na regulação dos usos dos espaços públicos. No caso estudado, a partir da perspectiva da geografia jurídica, evidenciou-se uma tendência no sentido de que as mudanças de regulação previstas acabariam por resultar na separação entre a área portuária e o entorno no que se refere às normas jurídicas aplicáveis. Isto é, poderiam ser estabelecidas para o Cais Mauá normas de conteúdo diverso das aplicáveis às ruas e praças do Centro Histórico de Porto Alegre.

O projeto de revitalização implicou na conformação da área do porto organizado como um espaço jurisdicional, com a gestão sendo transferida da administração pública para uma empresa privada por intermédio de um contrato de arrendamento. Sob a ótica da geografia jurídica, estariam dadas as condições para o Cais Mauá se consolidar como um lugar normativamente diferenciado do seu entorno, porque ali a regulação jurídica das práticas espaciais poderia assumir contornos específicos. Se a implementação do projeto de revitalização tivesse sido exitosa, isso provavelmente implicaria no advento de uma regulação jurídica condizente com a exploração econômica da área para fins de turismo, lazer e negócios, que resultaria no controle seletivo do público e reforçaria a alocação desigual de recursos para a promoção de usos públicos nos espaços urbanos de Porto Alegre. A articulação de movimentos de contestação ao projeto de revitalização, nesse sentido, parece ter sido fundamental para que essas tendências não se confirmassem, embora o desfecho de tal disputa permaneça, ainda, incerto.

\section{NOTAS}

[1] Remonta às décadas de 1940 e 1950 um outro conjunto de estudos que procuraram discutir as relações entre o direito e a geografia, influenciados pela tradição do Direito Comparado. No Brasil, um trabalho representativo dessa literatura é Santos (1954). Embora escape ao escopo deste artigo aprofundar esse ponto, é inequívoca a descontinuidade dessa literatura para com o que se conhece contemporaneamente por geografia jurídica (para uma revisão crítica deste campo de estudos nas últimas décadas, cf. DELANEY, 2015). 
[2] Expressões afins como "reabilitação urbana", "regeneração urbana" ou "renovação urbana" são, em grande medida, utilizadas de modo intercambiável para fazer referência ao mesmo fenômeno, embora possam traduzir modelos de intervenção urbanística distintos do ponto de vista do urbanismo.

[3] Para Arantes (2000), por exemplo, as práticas de revitalização e gentrificação são compreendidas como representativas de um mesmo fenômeno, o culturalismo de mercado.

[4] Maiores informações estão disponíveis no website oficial do projeto Porto Maravilha (PREFEITURA DO RIO DE JANEIRO, 2019). Na prática, a modelagem desta operação urbana consorciada guarda uma peculiaridade, que é a venda de todo o estoque de CEPACs pelo poder público em um lote único e indivisível. A Caixa Econômico Federal, vencedora do leilão, criou um fundo para negociar os CEPACs com o mercado imobiliário, solução com resultados aquém dos esperados, devido à baixa procura desses títulos por investidores. Para análises acadêmicas do projeto Porto Maravilha, cf., entre outros, Sarue (2015), Werneck (2016) e Vivian (2019).

[5] Para descrições acadêmicas do Projeto Novo Recife sob diferentes perspectivas, cf., entre outros, Barbosa (2014), Veras (2014) e Vivian (2019).

[6] Para uma síntese das disputas envolvendo o projeto Porto Maravilha, cf. a reportagem de Venturini (2016).

[7] Um retrato do conflito urbano envolvendo o Cais Estelita é apresentado em reportagem de Lima (2018).

[8] A definição legal de "porto organizado" (artigo 2o, I) é ainda mais circunscrita e diz respeito ao equipamento público voltado às necessidades de navegação, de movimentação de passageiros ou de movimentação e armazenagem de mercadorias (BRASIL, 2013).

[9] O Código Civil de 2002 distingue três categorias de bens imóveis (artigo 99) integrantes do domínio público: os bens de uso comum do povo, os bens de uso especial e os bens dominicais (ou dominiais). A partir desta classificação legal, os doutrinadores do direito administrativo brasileiro, em geral, consideram que os bens de uso comum do povo destinam-se à utilização geral pela coletividade, ao passo que os bens de uso especial comportam limitações de acesso, pois são voltados à consecução das atividades administrativas. Os bens dominicais, por sua vez, têm uma característica residual, estando sujeitos à alienação se observadas as exigências legais, já que não possuem uma destinação pública especificamente definida, apesar de pertencerem ao patrimônio público. Para uma análise da matéria na perspectiva da dogmática jurídica, consulte Marques Neto (2009).

[10] Isso independe do fato desses bens não estarem expressamente elencados no art. 20 da Constituição Federal (BRASIL, 1988), uma vez que tal enumeração não é taxativa, conforme reconhecido pela doutrina e jurisprudência.

[11] Uma análise aprofundada das inovações da Lei dos Portos pode ser encontrada em Farranha, Frezza e Barbosa (2015).

[12] Para uma discussão sobre paradigmas em sociologia urbana, ver Konzen (2011).

[13] Por exemplo, uma determinada norma urbanística em princípio válida para todo o perímetro municipal, que é um espaço jurisdicional, pode não ser aplicável dentro dos limites de uma Área Especial de Interesse Urbanístico, se este espaço jurisdicional for estabelecido pela legislação municipal.

[14] Por exemplo, em um município em que a venda ambulante é vedada, a fiscalização municipal pode controlar com rigor essa prática em zonas da cidade onde se situam as atrações turísticas e, ao mesmo tempo, tolerá-la no restante da cidade.

[15] Por exemplo, em uma vila ou favela, tanto quanto em um condomínio fechado, podem vigorar normas especificas sobre a compra e venda de terrenos e edificações que não são aplicáveis ao entorno.

[16] Para uma discussão do significado das obras públicas de modernização da área portuária, é referência o trabalho de Alves (2005).

[17] Cf. Decreto Estadual n. 36.140, de 30 de agosto de 1995, do Governo Antônio Britto (PMDB); Decreto Estadual n. 39.454, de 30 de abril de 1999, do Governo Olívio Dutra (PT); Decreto Estadual n. 42.256, de 22 de maio de 2003, do Governo Germano Rigotto (PMDB); e Decreto Estadual n. 45.187, de 27 de julho de 2007, do Governo Yeda Crusius (PSDB) (ESTADO DO RIO GRANDE DO SUL, 1995, 1999, 2003, 2007).

[18] Selecionado entre três grupos concorrentes, o consórcio vencedor era liderado por uma empresa de consultoria sediada em Porto Alegre, que apresentou estudos em parceria com uma das maiores construtoras do Brasil, o escritório de arquitetura de um conhecido urbanista do sul do país e quatro empresas espanholas especializadas em transporte, logística urbana e gestão de projetos imobiliários e turísticos (ESCOLHIDO, 2008). 
[19] A duplicação da altura máxima das edificações no setor Docas, que passou de 52 para 100 metros (art. 9o), viabilizando a construção das torres comerciais, é um exemplo expressivo das modificações aprovadas no regime urbanístico da área.

[20] É o que se depreende do documento intitulado Proposta de Metodologia e Execução (CAIS MAUÁ DO BRASIL S.A., 2010), que contém as principais informações acerca do empreendimento, subdividindo-se nos eixos Plano de Negócio, Plano Comercial do Negócio, Estudo Técnico e Modelo de Gestão do Cais Mauá. O acesso a essas informações documentais exige que a pessoa interessada consulte o expediente administrativo.

[21] Para uma análise detalhada dos arranjos e coalizões entre os diferentes atores envolvidos no processo de produção institucional da revitalização do Cais Mauá, ver Vivian (2019).

[22] Em 2017, o grupo "Cais Mauá de Todos" se transformaria em uma organização formal, a "Associação de Amigos do Cais do Porto" (AMACAIS).

[23] Mais análises acerca das disputas deflagradas pelos movimentos de contestação ao projeto de revitalização do Cais Mauá podem ser encontradas em Oliveira e Flores (2016), Vivian (2016) e Fernandes (2019).

[24] O parecer da PGE-RS, que subsidiou a decisão política do Governo Eduardo Leite (PSDB), identificou violações por parte da empresa a diversas cláusulas contratuais, entre as quais a ausência de obras relevantes, a não-manutenção da qualificação econômico-financeira da empresa arrendatária e o descumprimento da obrigação relativa ao pagamento do valor anual do arrendamento (ESTADO DO RIO GRANDE DO SUL, 2019).

\section{REFERÊNCIAS}

ALVES, Augusto. A construção do porto de Porto Alegre 1895-1930: modernidade urbanística como suporte de um projeto de estado. Dissertação (Mestrado) - Programa de Pós-Graduação em Planejamento Urbano e Regional. Universidade Federal do Rio Grande do Sul, Porto Alegre, 2005. $179 \mathrm{p.}$

ARANTES, Otília. Uma estratégia fatal: a cultura nas novas gestões urbanas. In: ARANTES, Otília; VAINER, Carlos; MARICATO, Ermínia (org.). A cidade do pensamento único: desmanchando consensos. Petrópolis: Vozes, 2000. p. 11-74.

AZUELA, Antonio. La ciudad, la propiedad privada y el derecho. México: El Colegio de México, 1989.

BARBOSA, David Tavares. Novos recifes, velhos negócios: política da paisagem no processo contemporâneo de transformações da Bacia do Pina - Recife/PE: uma análise do Projeto Novo Recife. Dissertação (Mestrado) - Programa de Pós-Graduação em Geografia, Universidade Federal de Pernambuco, Recife, 2014. 245 p.

BLOMLEY, Nicholas. Law, space, and the geographies of power. New York: Guilford Press, 1994.

BLOMLEY, Nicholas. Unsettling the city: urban land and the politics of property. New York:

Routledge, 2004.

BLOMLEY, Nicholas; DELANEY, David; FORD, Richard (org.). The legal geographies reader: law, power, and space. Oxford: Blackwell, 2001. 
BRASIL. Constituição da República Federativa do Brasil de 1988. Brasília: Presidência da República, 1988.

ttp://www.planalto.gov.br/ccivil_03/Constituicao/ConstituicaoCompilado.htm Acesso em: 02 mar. 2020.

BRASIL. Ministério dos Transportes. Convênio de Delegação n 01/97, de 27 de março de 1997. Convênio que entre si celebram a União, por intermédio do Ministério dos Transportes e o Estado do Rio Grande do Sul, para a administração e exploração dos Portos de Porto Alegre, Pelotas, Rio Grande e Cachoeira do Sul. Diário Oficial da União, Brasília, 11 de abril 1997, seção 3, p. 7854.

BRASIL. Decreto de 3 de junho de 2015. Define a área do Porto Organizado de Porto Alegre, Estado do Rio Grande do Sul. Brasília: Presidência da República, 2015. Disponível em: http://www.planalto.gov.br/CCIVIL_03/_Ato2015-2018/2015/Dsn/Dsn14199.htm Acesso em: 02 mar. 2020

BRASIL. Lei n. 10.257, de 10 de julho de 2001. Regulamenta os arts. 182 e 183 da Constituição Federal, estabelece diretrizes gerais da política urbana e dá outras providências. Brasília: Presidência da República, 2001.2 Disponível em: http://www.planalto.gov.br/ccivil_03/leis/LEIS_2001/L10257.htm Acesso em: 02 mar. 2020.

BRASIL. Lei n. 10.406, de 10 de janeiro de 2002. Institui o Código Civil. Brasília: Presidência da República, $2002 . \quad$ Disponível em: http://www.planalto.gov.br/ccivil_03/LEIS/2002/L10406compilada.htm. Acesso em: 02 mar. 2020. BRASIL. Lei $\mathbf{n} . \mathbf{1 2 . 8 1 5}$, de 05 de junho de 2013. Dispõe sobre a exploração direta e indireta pela União de portos e instalações portuárias e sobre as atividades desempenhadas pelos operadores portuários. Brasília: Presidência da República, 2013. Disponível em: http://www.planalto.gov.br/ccivil_03/_Ato2011-2014/2013/Lei/L12815.htm. Acesso em: 02 mar. 2020.

BRASIL. Lei n. 9.277, de 10 de maio de 1996. Autoriza a União a delegar aos municípios, estados da Federação e ao Distrito Federal a administração e exploração de rodovias e portos federais. Brasília: $\begin{array}{lllll}\text { Presidência da } & \text { República, } & \text { Disponível }\end{array}$ http://www.planalto.gov.br/ccivil_03/LEIS/L9277.htm Acesso em: 02 mar. 2020.

BRASIL. Presidência da República. Secretaria de Portos. Portaria n. 114, de 23 de março de 2016. Disciplina a exploração de áreas e instalações não afetas às operações portuárias para fins de revitalização de zonas portuárias. Diário Oficial da União, Brasília, 24 de março de 2016, seção 1, p. 2-3. 
BUTLER, Chris. Critical legal studies and the politics of space. Social \& Legal Studies, v. 18, n. 3, p. 313-332, 2009.

CAIS MAUÁ DE TODOS. Carta Aberta a Porto Alegre. Porto Alegre, 30 de outubro de 2015. Disponível em: https://www.facebook.com/caismauadetodos/posts/carta-aberta-a-portoalegremais-que-ruas-e-pra\%C3\%A7as-a-cidade-\%C3\%A9-parte-de-nosso-ser-/908573205902512/ Acesso em: 02 mar. 2020.

CAIS MAUÁ DO BRASIL S.A. Alerta sobre a permanência de pessoas não autorizadas no interior do Cais Mauá. Porto Alegre, 29 de agosto de 2014. Disponível em: <http://vivacaismaua.com.br/caismaua-brasil-s-alerta-para-perigo/>. Acesso em 02 mar. 2020.

CAIS MAUÁ DO BRASIL S.A. Proposta de metodologia e execução. Porto Alegre, 2010.

GOVERNO do Rio Grande do Sul rompe contrato com o consórcio Cais Mauá. Correio do Povo, Porto Alegre, 30 de maio de 2019. Disponível em: https://www.correiodopovo.com.br/not\%C3\%ADcias/pol\%C3\%ADtica/governo-do-rio-grande-dosul-rompe-contrato-com-o-cons\%C3\%B3rcio-cais-mau\%C3\%A1-1.342396. Acesso em: 02 mar. 2020.

DELANEY, David. The spatial, the legal and the pragmatics of world-making: nomospheric investigations. New York: Routledge, 2010.

DELANEY, David. Legal geography I: constitutivities, complexities, and contingencies. Progress in Human Geography, v. 39, n. 1, p. 96-102, 2015.

EM AUDIÊNCIA lotada no União, movimentos criticam projeto de revitalização do Cais Mauá. Sul21, Porto Alegre, 19 de setembro de 2015. Disponível em: < https://www.sul21.com.br/cidades/2015/09/em-audiencia-lotada-no-uniao-movimentoscriticam-projeto-de-revitalizacao-do-cais-maua/ Acesso em: 02 mar. 2020.

ESCOLHIDO grupo. Correio do Povo, Porto Alegre, ano 113, n. 303, 29 de julho de 2008.

ESTADO DO RIO GRANDE DO SUL. Decreto Estadual n. 36.140, de 30 de agosto de 1995. Institui um Grupo de Trabalho com a finalidade de estudar a revitalização de parte do Cais do Porto de Porto Alegre e dá outras providências. Disponível em: http://www.al.rs.gov.br/legis/M010/M0100099.ASP?Hid_Tipo=TEXTO\&Hid_TodasNormas=12083 \&hTexto=\&Hid_IDNorma=12083. Acesso em: 02 mar. 2020.

ESTADO DO RIO GRANDE DO SUL. Decreto Estadual n. 39.454, de 30 de abril de 1999. Institui Grupo de Trabalho com a finalidade de reavaliar o Porto de Porto Alegre. Disponível em: http://www.al.rs.gov.br/legis/M010/M0100099.ASP?Hid_Tipo=TEXTO\&Hid_TodasNormas=4874\& hTexto=\&Hid_IDNorma=4874. Acesso em: 02 mar. 2020. 
ESTADO DO RIO GRANDE DO SUL. Decreto Estadual n. 42.256, de 22 de maio de 2003. Institui Comissão com a finalidade de efetuar estudos para a revitalização do Cais Mauá, situado no Porto da cidade de Porto Alegre. Disponível em: http://www.al.rs.gov.br/legis/M010/M0100099.ASP?Hid_Tipo=TEXTO\&Hid_TodasNormas=46382 \&hTexto=\&Hid_IDNorma=46382. Acesso em: 02 mar. 2019.

ESTADO DO RIO GRANDE DO SUL. Decreto Estadual n. 45.187, de 27 de julho de 2007. Institui a Comissão Técnica de Avaliação e Seleção dos estudos relativos ao Projeto de Revitalização do Cais Mauá e dá outras providências. Disponível em: http://www.al.rs.gov.br/filerepository/repLegis/arquivos/DEC\%2045.187.pdf. Acesso em: 02 mar. 2020.

ESTADO DO RIO GRANDE DO SUL. Edital de Concorrência Internacional n. 01/2010, de 8 de julho de 2010. Revitalização do Cais Mauá, por meio da celebração de contrato de arrendamento de área portuária não operacional, incluindo a construção, implantação, manutenção, conservação, melhoria, gestão, exploração e operação (por meio de operadores especializados nas áreas da cultura, lazer, entretenimento, turismo e empresarial) de um complexo empresarial de cultura, lazer, entretenimento e turismo ("Complexo Cais Mauá"). Disponível em: http://www.cecom.rs.gov.br/index.php?menu=editaldetalhe\&id=1678\&link=Y29kdD0mY29kbT05 JmNvZHM9Jm9yZ3M9JmROYWk9JmROYWY9JnBIc3E9MSZwcm9jZXNzbzOmb2JqZXRvPSZvcmQ9. Acesso em: 02 mar. 2019.

ESTADO DO RIO GRANDE DO SUL. Procuradoria-Geral do Estado. Parecer 17.623, de 30 de maio de 2019. Disponível em: http://sid.pge.rs.gov.br/pareceres/pa17623.pdf. Acesso em: 02 mar. 2020. FARRANHA, Ana Claudia; FREZZA, Conrado; BARBOSA, Fabiana de Oliveira. Nova Lei dos Portos: desafios jurídicos e perspectivas de investimentos. Revista Direito GV, São Paulo, v. 1, n. 11, p.89116, 2015.

FERNANDES, Karina M. G. Direito à cidade, colonialidade e território: a disputa pelo Cais Mauá, em Porto Alegre. Tese (Doutorado) - Programa de Pós-Graduação em Direito, Universidade do Vale do Rio dos Sinos - Unisinos, São Leopoldo, 2019. 449 p.

KONZEN, Lucas P. A mudança de paradigma em sociologia urbana: do paradigma ecológico ao socioespacial. Revista de Ciências Humanas, v. 45, n. 1, p. 79-99, 2011.

KONZEN, Lucas P. Norms and space: understanding public space regulation in the tourist city. Lund: Lund University, 2013.

LEFEBVRE, Henri. Le droit à la ville. Paris: Anthropos, 1968.

LEFEBVRE, Henri. La production de l'espace. 4. ed. Paris: Anthropos, 2000 [1974]. 
LEITE, Rogerio Proença. Contra-usos da cidade: lugares e espaço público na experiência urbana contemporânea. Campinas: Unicamp, 2004.

LIMA, Juliana Domingos de. Quais as disputas em torno do Projeto Novo Recife. Nexo Jornal, São Paulo, 20 de novembro de 2018 . Disponível em: https://www.nexojornal.com.br/expresso/2018/11/20/Quais-as-disputas-em-torno-do-ProjetoNovo-Recife . Acesso em: 02 mar. 2020.

MARQUES NETO, Floriano de Azevedo. Bens públicos. Belo Horizonte: Fórum, 2009.

MITCHELL, Don. The right to the city: social justice and the fight for public space. New York: The Guilford Press, 2003.

MUNICÍPIO entregará licença ambiental ao Cais Mauá nesta terça. Portal da Prefeitura de Porto Alegre, Porto Alegre, 05 de dezembro de 2017. Disponível em: <http://www2.portoalegre.rs.gov.br/portal_pmpa_novo/default.php?p_noticia=999193977\&MU NICIPIO+ENTREGARA+LICENCA+AMBIENTAL+AO+CAIS+MAUA+NESTA+TERCA>. Acesso em: 02 mar. 2020.

OCUPA CAIS MAUÁ. Carta aberta à população de Porto Alegre: como queremos nosso Cais Mauá? Porto Alegre, 24 de novembro de 2014. Disponível em: https://www.facebook.com/ocupacaismaua/posts/368723943297544:0/. Acesso em: 02 mar. 2030.

OLIVEIRA, Clarice M.; FLORES, Rafael K.. Conflitos no espaço urbano: um Cais Mauá de todos? Revista Brasileira de Estudos Urbanos e Regionais, v. 18, n. 2, p. 224-239, 2016.

PORTO ALEGRE. Plano Diretor de Desenvolvimento Urbano Ambiental. Lei Complementar no 434, de 1 o de dezembro de 1999, atualizada e compilada até a Lei Complementar no 667, de 3 de janeiro de 2011, incluindo a Lei Complementar 646, de 22 de julho de 2010. Porto Alegre: Prefeitura de Porto Alegre, 2011. Disponível em: http://Iproweb.procempa.com.br/pmpa/prefpoa/spm/usu_doc/planodiretortexto.pdf. Acesso em: 02. mar. 2020.

PORTO ALEGRE. Lei Complementar n. 638, de 4 de março de 2010. Estabelece regras para a utilização da área do Cais Mauá e dá outras providências. Disponível em: http://www2.portoalegre.rs.gov.br/cgi-bin/nphbrs?s1=000030964.DOCN.\&I=20\&u=/netahtml/sirel/simples.html\&p=1\&r=1\&f=G\&d=atos\&SECT1 =TEXT. Acesso em: 02 mar. 2020.

PORTO ALEGRE. Assinado contrato de revitalização do Cais Mauá. Diário Oficial de Porto Alegre, Porto Alegre, 24 de dezembro de 2010, p. 1. 
PREFEITURA DO RIO DE JANEIRO. Companhia de Desenvolvimento Urbano da Região do Porto do Rio de Janeiro. Porto Maravilha. Disponível em: <http://portomaravilha.com.br>. Acesso em: 02 mar. 2020.

QUEREMOS que Cais Mauá seja tudo aquilo que possa significar", diz Leite ao anunciar rescisão de contrato. Portal do Governo do Estado do Rio Grande do Sul, Porto Alegre, 30 de maio de 2019. Disponível em: <https://www.estado.rs.gov.br/queremos-que-cais-maua-seja-tudo-aquilo-quepossa-significar-diz-leite-ao-anunciar-rompimento-de-contrato>. Acesso em: 02 mar. 2020.

SANTOS, José Nicolau dos. Fundamentos da geografia jurídica. Revista da Faculdade de Direito da UFPR, v. 2, p. 174-261, 1954.

SARUE, Betina. Grandes projetos urbanos e a governança de metrópoles: o caso do Porto Maravilha no Rio de Janeiro. Dissertação (Mestrado) - Programa de Pós-Graduação em Ciência Política, Universidade de São Paulo, São Paulo, 2015. 142 p.

SMITH, Neil. A gentrificação generalizada: de uma anomalia local à "regeneração" urbana como estratégia urbana global. In: BIDOU-ZACHARIASEN, Catherine (org.). De volta à cidade: dos processos de gentrificação às políticas de "revitalização" dos centros urbanos. Tradução de Helena Silva. São Paulo: Annablume, 2006. p. 59-88.

STAEHELI, Lynn A.; MITCHELL, Don. The people's property? Power, politics, and the public. New York: Routledge, 2008.

TUMULTO marca apresentação do estudo de impacto ambiental. GaúchaZH, Porto Alegre, 18 de setembro de 2015. Disponível em: <http://zh.clicrbs.com.br/rs/porto-alegre /noticia/2015/09/caismaua-tumulto-marca-apresentacao-do-estudo-de-impacto-ambiental-4851616.html/>. Acesso em: 02 mar. 2020.

VENTURINI, Lilian. De vitrine política ao debate sobre o papel do poder público: o que é o Porto Maravilha. Nexo Jornal, São Paulo, 16 de julho de 2016. Disponível em: https://www.nexojornal.com.br/expresso/2016/07/16/De-vitrine-política-ao-debate-sobre-opapel-do-poder-público.-O-que-é-o-Porto-Maravilha . Acesso em: 02 mar. 2020.

VERAS, Lúcia Maria S. C. Paisagem-postal: a imagem e a palavra na compreensão de um Recife urbano. Tese (Doutorado) - Programa de Pós-Graduação em Desenvolvimento Urbano, Universidade Federal de Pernambuco, Recife, 2014. 472 p.

VIVIAN, Mariana M. Revitalizações urbanas e disputas pelo espaço público: o caso do Cais Mauá, em Porto Alegre. Trabalho de Conclusão de Curso (Graduação) - Faculdade de Direito, Universidade Federal do Rio Grande do Sul, Porto Alegre, 2016. 108 p. 
VIVIAN, Mariana M. Transformações urbanas no século XXI: trajetórias e produção institucional das políticas de waterfront regeneration no Brasil. Dissertação (Mestrado) - Programa de PósGraduação em Sociologia, Universidade Federal do Rio Grande do Sul, Porto Alegre, 2019. 344 p. WERNECK, Mariana. Porto Maravilha: agentes, coalizões de poder e neoliberalização no Rio de Janeiro. Dissertação (Mestrado) - Instituto de Pesquisa e Planejamento Urbano e Regional, Universidade Federal do Rio de Janeiro, Rio de Janeiro, 2016. 239 p.

YIN, Robert K. Estudo de caso: planejamento e métodos. 2. ed. Tradução de Daniel Grassi. Porto Alegre: Bookman, 2001.

\section{AGRADECIMENTOS}

Este artigo é um dos produtos do projeto de pesquisa "Geografias jurídicas da cidade: estudos empíricos sobre a regulação do domínio público", desenvolvido com a colaboração do Grupo de Pesquisa Direito e Sociedade (GPDS) da Universidade Federal do Rio Grande do Sul (UFRGS). Os autores estendem os agradecimentos aos pareceristas anônimos da Revista de Direito da Cidade, cujas contribuições foram de grande valia para o aperfeiçoamento do trabalho.

Trabalho enviado em 22 de janeiro de 2019

Aceito em 12 de abril de 2020 